\title{
Linkages of Subtropical Stratospheric Intraseasonal Intrusions with Indian Summer Monsoon Deficit Rainfallo
}

\author{
SUVARNA FADNAVIS AND RAJIB CHATTOPADHYAY \\ Indian Institute of Tropical Meteorology, Pune, India
}

(Manuscript received 21 June 2016, in final form 14 March 2017)

\begin{abstract}
The authors investigate the life cycle of a strong subtropical stratospheric intrusion event and propose a hypothesis through which it might reduce the intensity of the Indian summer monsoon (ISM) rainfall (ISMR) after the monsoon onset during June 2014. The diagnostic analysis of ERA-Interim data revealed that stratospheric intrusion occurs in the region of the subtropical westerly jet (SWJ) as a result of Rossby wave breaking (RWB). The RWB event is associated with eddy shedding. These eddies transport extratropical stratospheric mass and energy fluxes downward and southward to north India (NI). As a result, the intrusion spreads dry, cold, and ozone-rich air deep into the troposphere $(\sim 500 \mathrm{hPa})$ over the NI. It enhanced the static stability and weakens the north-south upper-tropospheric temperature gradient. The intrusion of cold and dry air persisted for the entire June, which might have inhibited northward propagation of ISM convection and could be responsible for prolonged hiatus in northward phase propagation of the ISM after onset. The relation between stratospheric intrusion events and ISMR from long-term data (1979-2007) is also investigated. The analysis shows that the stronger negative anomalies of rainfall are associated with stratospheric intrusions during break spells. Thus, the study reveals that stratospheric intrusion is an important factor that may influence ISMR deficit.
\end{abstract}

\section{Introduction}

The Indian summer monsoon rainfall (ISMR) is triggered during June through an abrupt onset, and subsequently its progression occurs over other Indian regions [during onset there is explosive growth of convection, crossequatorial flow, and kinetic energy (e.g., Krishnamurti 1985; Xavier et al. 2007)]. After the monsoon onset over Kerala, the first rainy phase during June is crucial for agricultural purposes and is characterized by the development of northward-propagating large-scale cloud bands that bring rainfall over the Indo-Gangetic Plain and the larger monsoon zone (Ashok et al. 2004; Rajeevan et al. 2010). It is observed that, after onset during the start of June, the monsoon rainbands cover the whole subcontinent in a span of a month. subsequently sets up the subseasonal fluctuations in rainfall over the monsoon trough zones,

Supplemental information related to this paper is available at the Journals Online website: http://dx.doi.org/10.1175/ JCLI-D-16-0463.s1.

Corresponding author: Suvarna Fadnavis, suvarna@tropmet. res.in which are manifested in the active and break cycles of monsoon. During an active spell, the rainfall amount over a larger area of central India is more than $5-10 \mathrm{~mm}^{-1 a y}{ }^{-1}$. During the break spell, it can fall below $2 \mathrm{~mm} \mathrm{day}^{-1}$. The oscillation leading to the active-break cycle is broadband and quasi periodic in nature with dominant spectral peaks in the 20-80 days and showing repeated northward propagations (Goswami 2012). Such quasi periodicity sometimes extends the active spells and the break spells. Prolonged active spells cause floods, and break spells may lead to deficit rainfall over several regions of India. In this regard, the prolonged break situation or absence of rainfall has received much attention in literature owing to its direct link with the agricultural productivity and hence gross domestic product (GDP) of India (Gadgil and Gadgil 2006).

It is observed during several years that, after onset, monsoon convection does not propagate northward, and there is an onset phase hiatus with a drastic reduction in rainfall (Subramanya 1984; Biswas et al. 1998; Raju et al. 2005). Such subdued rainfall is associated with the break phases over the central Indian region of the monsoon trough zone. The role of the Tibetan Plateau (TP) and the subtropospheric ridge over the Himalayan region were highlighted in Biswas et al. (1998) and Holbrook et al. (2014). 


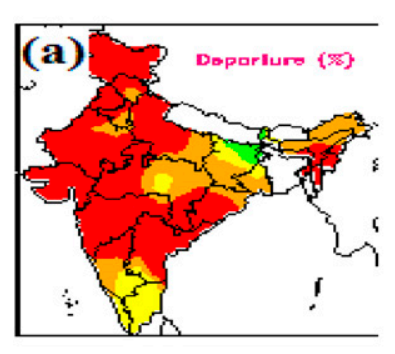

$-40-2002040$
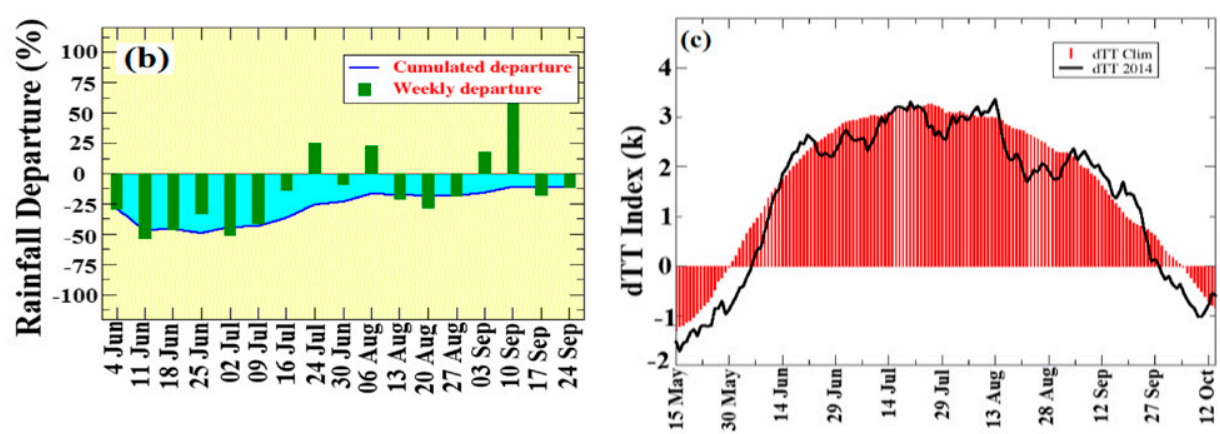

FIG. 1. (a) Spatial distribution of mean ISMR departure (\%) averaged for 5-25 Jun 2014 over India; (b) pentad variation (average for 5 days) of mean ISMR departure (\%) (obtained from http://www.tropmet.res.in/ kolli/mol/Monsoon/frameindex.html); and (c) troposphere temperature gradient (dTT; K). The dTT index is defined as the difference of upper-tropospheric temperature (averaged between $200-600 \mathrm{hPa}$ ) between a northern box $\left(5^{\circ}-35^{\circ} \mathrm{N}, 40^{\circ}-100^{\circ} \mathrm{E}\right)$ and a southern box $\left(15^{\circ} \mathrm{S}-5^{\circ} \mathrm{N}, 40^{\circ}-100^{\circ} \mathrm{E}\right)$.

Several other studies have reported the association between upper-tropospheric extratropical excursion and reduction of rainfall over the Indian region. For example Ramaswamy (1962) has proposed that the intrusion of the midlatitude trough may trigger monsoon deficit rainfall over the Indian region and lead to development of a break monsoon condition. Krishnan et al. (2000) have attributed it to an abrupt movement of anomalous Rossby waves originating from the Bay of Bengal traveling into northwest and central India. Samanta et al. (2016) reported that anticyclonic Rossby wave breaking over west Asia could influence the Indian summer monsoon (ISM) failure via cold and dry air advection. Other studies (Mapes and Zuidema 1996; Allen et al. 2009) delineate invasion of dry air from subtropical upper troposphere with tropical droughts. As can been seen above, there are scattered studies on ISM failure and phenomena in the upper troposphere (UT), but these studies do not provide information on linkages of stratospheric intrusions with ISM break-deficit.

Rossby wave breaking (RWB) is identified as a key factor affecting the dynamics of the upper troposphere and lower stratosphere. It is an important contributor to tropopause fold and the complex of stratospheretroposphere exchange processes (Waugh and Funatsu 2003). ERA-Interim (1979-2012) shows that tropopause fold formations are quite frequent over west Asia (eastern Mediterranean and Iran-Afghanistan region) (Weigel et al. 2012), and fold activity peaks in summer (Tyrlis et al. 2014). Studies based on shallow-water simulations (Hsu and Plumb 2000) and reanalysis data (Popovic and Plumb 2001) show that RWB facilitates eddy shedding (cutoff potential vorticity features) from the Tibetan anticyclone. During the monsoon season (June-September) the Asian summer monsoon (ASM) anticyclone becomes unstable, and it periodically sheds eddies to the west and occasionally to the east (Vogel et al. 2014). Splitting of the anticyclone and consequent westward eddy shedding has also been documented by other researchers: for example, He et al. (1987), Dunkerton (1995), and Popovic and Plumb (2001) reported that dissipation of Rossby waves could cause eddies to move predominately westward. Westward eddy shedding from the Tibetan anticyclone occurs 2-4 times per summer with a duration of $\sim(4-8)$ days. Several other studies (Waugh 2005; Konopka et al. 2010; Ploeger et al. 2012) showed that RWB is an important agent for the intrusion of extratropical lower-stratospheric (LS) air mass into the tropical UT. In brief, the RWB breaking could also be responsible for perturbing the monsoon climate in the UT (via energy and mass flux exchange between the extratropical lower stratosphere and tropical UT), similar to extratropical intrusions, which are known to interact with the monsoon.

Studies reported so far have mostly ignored the connection of stratospheric intrusion with ISM break-deficit. It motivates us to ask a question: if extratropical stratospheric cold and dry intrusion occurs over the Indian region or adjacent regions, then does it affect the ISMR deficit by enhancing static stability? To answer this question, we present a case study during the monsoon onset phase in June 2014 when there was a large rainfall deficit after onset in the second half of the month $(-40 \%$ departure from climatology; Fig. 1a and Fig. 1b). Associated with this, the upper-tropospheric temperature gradient (Xavier et al. 2007) index was also lower than climatology during the middle to end of June (Fig. 1c). Uppertropospheric warming influences the ISMR via a variation in the north-south temperature gradient (discussions in section 4). It suggests a weak (or reduction in) warming in the upper troposphere during the middle to end of June since the weakening of the upper-tropospheric warming could be related to the stratospheric intrusion.

We identify and document the sequence of events associated with the subtropical stratospheric intrusion that could be linked to the persistence of the monsoon 
TABLE 1. Monsoon break days during 1979-2007.

\begin{tabular}{ll}
\hline \hline Year & \multicolumn{1}{c}{ Break days } \\
\hline 1979 & 2-6 Jul, 14-29 Aug \\
1980 & 17-20 Jul, 13-15 Aug \\
1981 & 24-27 Aug \\
1982 & 1-8 Jul \\
1983 & 23-25 Aug \\
1984 & 27-29 Jul \\
1985 & 23-25Aug \\
1986 & 22-31 Aug \\
1987 & 23-25 Jul, 30 Jul-4 Aug, 8-13 Aug, 16-18 Aug \\
1988 & 14-17 Aug \\
1989 & 18-20 Jul, 30 Jul-3 Aug \\
1990 & \\
1991 & 4-11 Jul \\
1992 & 20-23 Jul, 7-13 Aug, 22-28 Aug \\
1993 & 3-7 Jul, 11-16 Aug \\
1994 & 10-12 Aug \\
1995 & 11-15 Jul, 9-14 Aug \\
1996 & 20-26 Jul, 16-21 Aug \\
1997 & 1-5 Jul, 12-16 Aug, 22-25 Aug \\
1998 & 1-9 Aug \\
1999 & 31 Jul-2 Aug, 26-30 Aug \\
2000 & 4-17 Jul, 21-31 Jul \\
2001 & 10-13 Jul, 19-21 Jul, 26-31 Aug \\
2002 & 7-14 Aug, 24-31 Aug \\
2003 & 18-22 Jul, 15-17 Aug \\
2004 & \\
2005 & \\
2006 & 2007
\end{tabular}

rainfall deficit after onset in June 2014 and stalled further propagation of the monsoon. We also investigate the occurrence of tropopause fold-stratospheric intrusion during several other rainfall deficit events (break spells) during the summer monsoon season of 1979-2007 and discuss the fidelity of the results obtained from the case study.

\section{Data and methods}

Stratospheric intrusions are associated with high potential vorticity, ozone amounts, and deficit water vapor. They may also affect tropospheric weather because of an irreversible isentropic mixing of stratospheric air (Appenzeller and Davies 1992; Fadnavis et al. 2010). To identify an intrusion, we analyze daily potential vorticity $(\mathrm{PV})$, winds, specific humidity $(q)$, tropopause, temperature, ozone mixing ratios, and relative humidity (RH) obtained from ERA-Interim data (Dee et al. 2011). Daily mean values are derived from 6-hourly data. We also used daily carbon monoxide $(\mathrm{CO})$, ozone mixing ratios, and outgoing longwave radiation from Atmospheric Infrared Sounder (AIRS) measurements. These parameters are analyzed for June 2014.
Climatological means of the above fields are derived from data for the period 1979-2015. Anomalies in daily temperature-RH for June 2014 represent the difference between temperature-RH of that day in June 2014 and the daily climatological mean. We consider the dynamical tropopause as the isosurface of 2 PVU (1 PVU = $10^{-6} \mathrm{~K} \mathrm{~m}^{2} \mathrm{~kg}^{-1} \mathrm{~s}^{-1}$ ) (Hoskins et al. 1985) or the $380 \mathrm{~K}$ isentropic surface (Holton et al. 1995).

We also analyze the occurrence of tropopause fold during all break periods listed in Table 1 (for the period 1979-2007) over two regions: 1) the northwest India, Pakistan, and Afghanistan region, $27^{\circ}-35^{\circ} \mathrm{N}, 60^{\circ}-78^{\circ} \mathrm{E}$ and 2) the north India (NI) and TP region, $27^{\circ}-35^{\circ} \mathrm{N}$, $78^{\circ}-110^{\circ} \mathrm{E}$. For ease of reference in the discussions that follow, these regions are named Region-1 and Region-2, respectively. Break periods listed in Table 1 are adopted from Rajeevan et al. (2010). To understand the relation of stratospheric intrusions with ISMR, we show the bivariate probability distribution function (BPDF) of the two variables. For this purpose, we take daily ISMR anomalies over central India $\left(12^{\circ}-25^{\circ} \mathrm{N}, 68^{\circ}-80^{\circ} \mathrm{E}\right)$ and $\mathrm{PV}$ at $250 \mathrm{hPa}$ over Region-1 and Region-2.

\section{Results}

\section{a. Meteorological PV analysis}

Figures 2a-e show the zonal cross section of PV for every alternate day during 10-18 June 2014. It is evident that stratospheric PV (PV > 2 PVU) slopes downward and westward through the tropopause fold here tropopause is considered as the $380-\mathrm{K}$ surface over the Indian region $\left(8^{\circ}-40^{\circ} \mathrm{N}, 70^{\circ}-105^{\circ} \mathrm{E}\right)$. Intrusions penetrate into the troposphere $\sim(300-400) \mathrm{hPa}$, and evidence of the deepest intrusion is observed on 14-15 June 2014 reaching to the lower troposphere $\sim 500 \mathrm{hPa}$ (also see online supplemental Fig. S1). Figures 2a-e also show that the tropopause fold moves eastward during 10-18 June. The meridional cross sections of PV (Figs. 2f-j) show that intrusion take the shape of a tilted $\mathrm{V}$ slopping down over $20^{\circ}-40^{\circ} \mathrm{N}$. Similar results of stratospheric intrusion through tropopause fold over other regions have been reported in the past (Waugh and Polvani 2000; Reid and Vaughan 2004; Allen et al. 2009; Tyrlis et al. 2014).

\section{b. Evidence of Rossby wave breaking during stratospheric intrusions}

Rossby wave breaking is known to facilitate stratospheric intrusions into the troposphere (Scott and Cammas 2002). Rossby waves may take a form of tropopause fold in the vertical direction (Allen et al. 2009). The eastward movement of the tropopause fold seen in Figs. 2a-e may be associated with a Rossby wave 

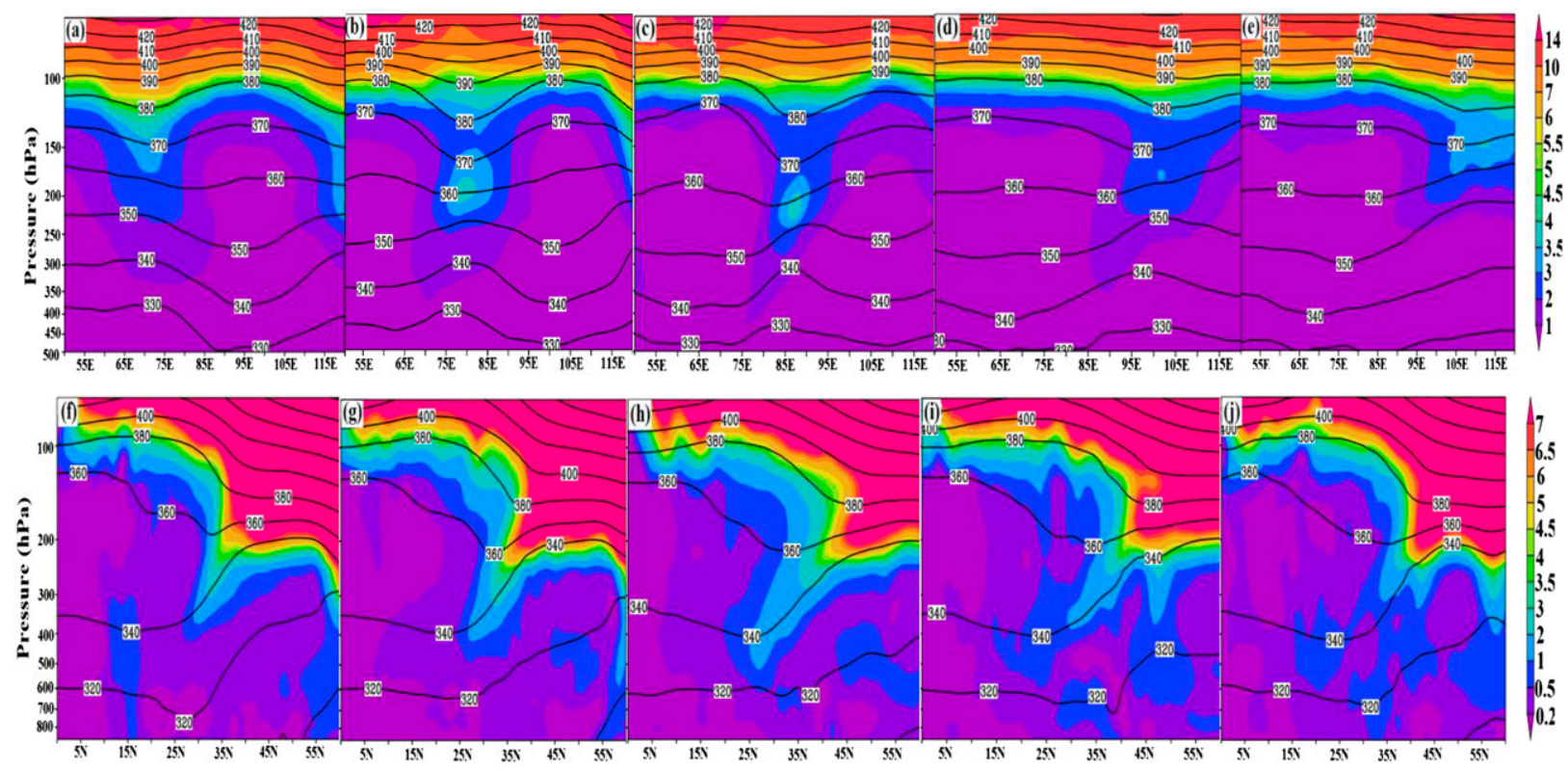

FIG. 2. Zonal cross section of potential vorticity (PVU) (color shades) averaged over $25^{\circ}-40^{\circ} \mathrm{N}$ for (a)-(e) $10,12,14,16$, and 18 Jun 2014 , respectively. Meridional cross section of potential vorticity (PVU) averaged over (f) $60^{\circ}-80^{\circ} \mathrm{E}$ for $10 \mathrm{Jun},(\mathrm{g}) 70^{\circ}-90^{\circ} \mathrm{E}$ for $12 \mathrm{Jun},(\mathrm{h}) 80^{\circ}-90^{\circ} \mathrm{E}$ for $14 \mathrm{Jun}$, (i) $85^{\circ}-100^{\circ} \mathrm{E}$ for $16 \mathrm{Jun}$, and (j) $85^{\circ}-95^{\circ} \mathrm{E}$ for $18 \mathrm{Jun} 2014$. Contour lines indicate potential temperature $\theta$. The contour line corresponding to the $380-\mathrm{K}$ isentropic surface represents the tropopause.

traveling along a subtropical westerly jet (SWJ). These RWBs can be identified from PV distribution at $350 \mathrm{~K}$ (Strong and Magnusdottir 2008; Samanta et al. 2016) and $370 \mathrm{~K}$ (Homeyer and Bowman 2013). RWB is manifested by the rapid and large-scale irreversible overturning of PV contours on isentropic surfaces (McIntyre and Palmer 1985; Strong and Magnusdottir 2008). The features of the RWB that appears in PV at $350 \mathrm{~K}$ is equatorial advection of high PV values with a steep gradient (Strong and Magnusdottir 2008; Barnes and Hartmann 2012) and the downstream PV trough location relative to the breaking axis (indicated by a line in Fig. 3a).The important characteristic of RWB is the southward movement of PV from the westerly jet (Samanta et al. 2016). Krishnan et al. (2009) reported that the extent of the westerly jet is north of $30^{\circ} \mathrm{N}$.

Figures 3a-f exhibit variation of PV (alternate days during 10-18 June 2014) at the 350-K isentropic surface and wind anomalies at $200 \mathrm{hPa}$. These figures show the RWB occurs during 10-18 June. Wind anomalies at $200 \mathrm{hPa}$ show cyclonic circulation along the breaking axis (depicted in Fig. 2a). On 10 June, an RWB occurs over northwest India that traverses over NI $\left(\sim 30^{\circ} \mathrm{N}\right.$, $80^{\circ} \mathrm{E}$ ) (Fig. 3a). It facilitates tropopause fold and subsidence of stratospheric air mass in the troposphere $(\sim 300 \mathrm{hPa})$ (Fig. 2a). An increase in momentum flux toward the equator due to RWB is also reported by Strong and Magnusdottir (2008). The RWB splits the
Asian summer monsoon anticyclone into two anticyclones: one over Iran and another over the Tibetan region (Fig. 3a). The Iranian and Tibetan anticyclone separated by RWB is better portrayed in PV distribution at the $370-\mathrm{K}$ isentropic surface (Figs. 4a-c). The RWB sheds stratospheric PV equatorward and westward over the Indian region (discussed later in this section). On 12 June the RWB (or tropopause fold) moves eastward along with the SWJ and is positioned over NI. The associated anticyclones also moved eastward. On this day, the RWB is more intense, and the eddy spreads over Iran, Pakistan, and the northwest India regions (Figs. 2b, 3b, 4b). On 14 June, the RWB is positioned over the Tibetan Plateau. The anticyclones further intensify, and a streamer of extratropical high PV protrudes over the Tibetan Plateau $\left(\sim 25^{\circ} \mathrm{N}, 85^{\circ} \mathrm{E}\right)$ (Figs. $2 \mathrm{c}, \mathrm{h}, 3 \mathrm{c}$ ). On this day the RWB is intense, and the tropopause fold is deeper, up to $\sim 300 \mathrm{hPa}$ (Fig. 2c and supplemental Fig. S1). RWB continues during 15-17 June along with eastward-moving SWJ and PV eddy shedding over the eastern Tibetan Plateau (Figs. 2d, 3d, 4d). On 18 June, a streamer of high PV and cyclonic circulation appears over TP $\left(90^{\circ}-110^{\circ} \mathrm{E}\right)$, and the anticyclone pertaining to Iran moved over NI. Shallow stratospheric intrusion occurs over northeastern Tibet (Figs. 1e, 2e, 3e). On 20 June, there is no indication of southward propagation of high PV values indicating no event of RWB in the vicinity of the Indian region (Fig. 3f). 

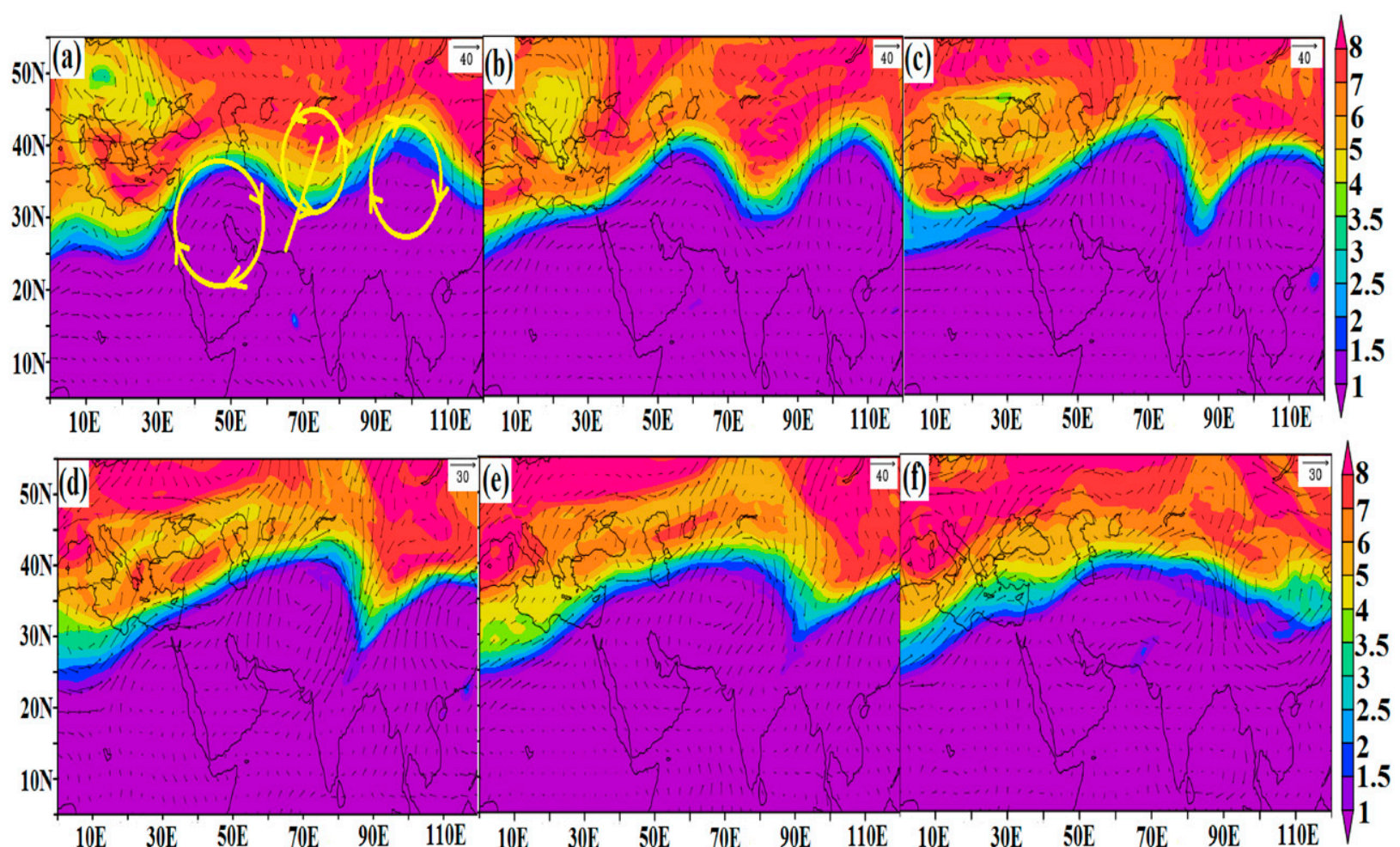

FIG. 3. Spatial distribution of potential vorticity (PVU) (color shades) at the 350-K level and wind anomalies at $200 \mathrm{hPa}$ for (a)-(f) 10 , $12,14,16,18$, and 20 Jun 2014, respectively. Wind vectors are represented by black arrows. The anticyclone and cyclonic circulation and RWB axis are indicated in (a).

It is interesting to observe the PV distribution on the 370-K isentropic surface (Figs. 4a-f). Figure 4a shows that, on 10 June 2014 , RWB $\left(35^{\circ} \mathrm{N}, 65^{\circ} \mathrm{E}\right)$ splits the Asian summer monsoon anticyclone into Iranian and Tibetan anticyclones. The bimodal structure of the Asian summer monsoon anticyclone, Iranian, and Tibetan mode is found by Zhang et al. (2002) and later reported by a number of authors (Ren-Chang et al. 2011; Garny and Randel 2013; Nützel et al. 2016). Figures 4a-e show that extratropical stratospheric PV $(\mathrm{PV}>2)$ flows from the RWB region and travels equatorward and westward into the Iranian anticyclone. Westward eddy shedding from the TP anticyclone is also observed by Hsu and Plumb (2000) and Popovic and Plumb (2001). In agreement with these studies, the present analysis also shows equatorward and westward eddy shedding events during 10-18 June 2014.

\section{c. Ozone and relative humidity variations}

We analyze the daily variation of ozone mixing ratios $\left(\mathrm{O}_{3}\right)$ and $\mathrm{RH}$ during June 2014. Figures $5 \mathrm{a}-\mathrm{j}$ show zonal and meridional cross sections of $\mathrm{O}_{3}$ during 10-18 June 2014 (plot shows every alternate day). These figures depict stratospheric air mass rich in $\mathrm{O}_{3} \sim(120-160) \mathrm{ppb}$ crossing the tropopause (2-PV line) and intruding deep into the troposphere $\sim 500 \mathrm{hPa}$. The distribution of $\mathrm{RH}$ shows that this air is extremely dry $(\mathrm{RH}<5 \%)$ (Figs. 5k-o, 7b) and descends to the surface, reducing RH there to $\sim 40 \%$. Another checkpoint that confirms the stratospheric intrusion is a tracer-tracer correlation (Fischer et al. 2000; Pan et al. 2004; Fadnavis et al. 2010). AIRS-observed $\mathrm{CO}$ and $\mathrm{O}_{3}$ show strong negative correlation (-0.72) during 10-18 June 2014 (see supplemental Fig. S2). Thus, $\mathrm{PV}$ analysis, high $\mathrm{O}_{3}-$ low $\mathrm{RH}$, and high $\mathrm{O}_{3}$-low $\mathrm{CO}$ analysis confirms the events of stratospheric intrusions during 10-18 June 2014.

The spatial map of daily temperature anomaly (11-18 June) at $200 \mathrm{hPa}$ over the NI and TP region is shown in Fig. 6a. The variations in temperature anomalies are plotted in each panel. The plot shows anomalous warming and cooling in patterns showing a signature of wave-phase propagation (positive and negative temperature anomalies are indicated by plus and minus signs) in the subtropical region $\left(40^{\circ}-50^{\circ} \mathrm{N}\right)$. Negative temperature anomalies move eastward during 11-18 June 2014 (indicated by arrows). Similar eastward movement of the tropopause fold during this period is observed in Figs. 2a-e. Figure 6b shows a Hovmöller diagram of 


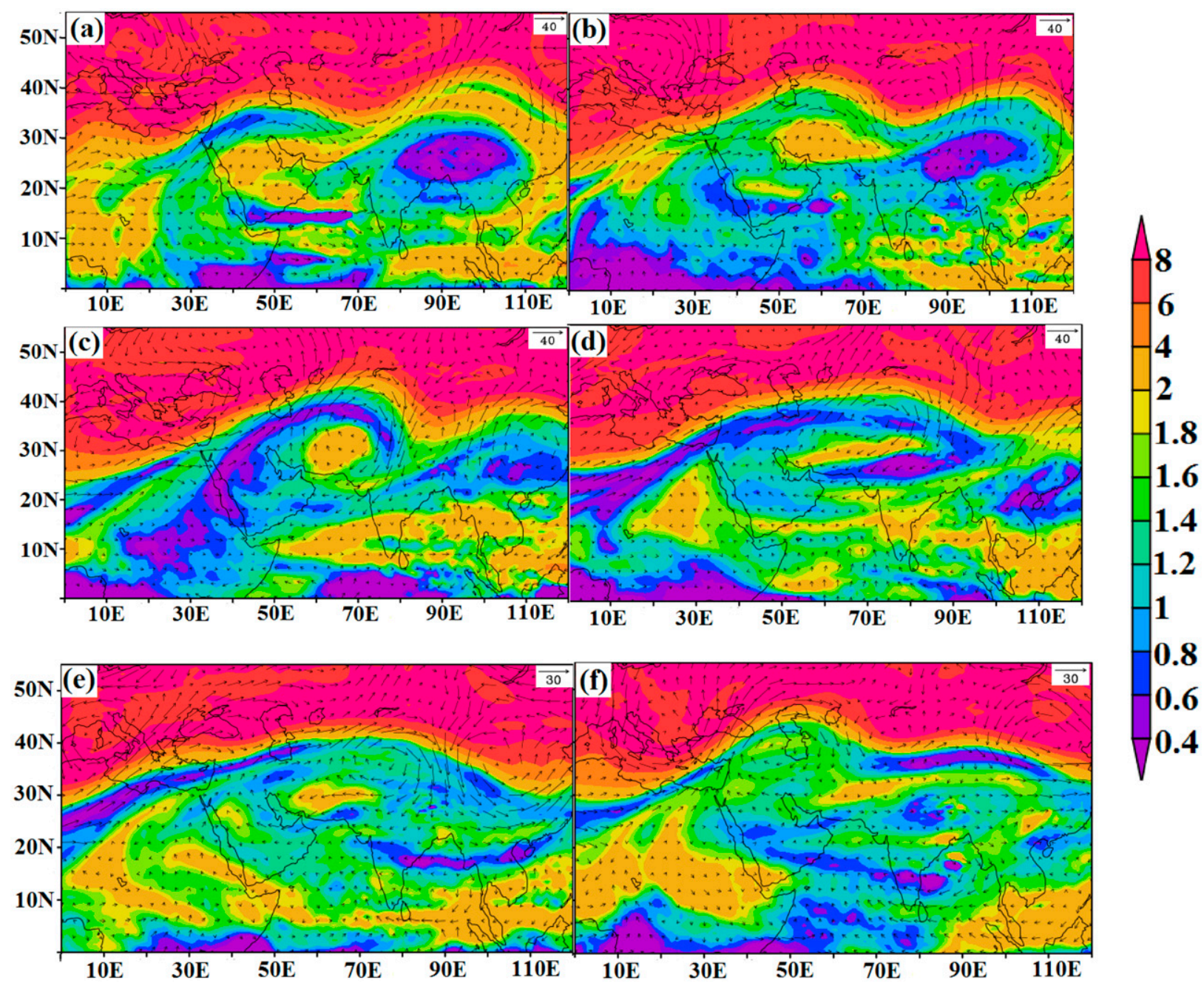

FIG. 4. Spatial distribution of potential vorticity (PVU) (color shades) at the 370-K level and wind anomalies at $200 \mathrm{hPa}$ for (a)-(f) 10,12 , 14, 16, 18, and 20 Jun 2014, respectively. Wind vectors are represented by black arrows.

temperature anomalies (averaged $30^{\circ}-50^{\circ} \mathrm{N}$ ) plotted at $400 \mathrm{hPa}$ for the entirety of June 2014. It shows a clear evidence of wavelike eastward propagation (similar to tropopause fold in Fig. 2) accompanied by cold intrusions (negative temperature anomalies) at $400 \mathrm{hPa}$ over NI $\left(70^{\circ}-90^{\circ} \mathrm{E}\right)$. This cold temperature air mass traversed the NI and TP region $\left(70^{\circ}-110^{\circ} \mathrm{E}\right)$ during 9-21 June and 21-30 June (shown by yellow lines). The time-height plot of anomalies in temperature averaged over the NI and TP region $\left(30^{\circ}-50^{\circ} \mathrm{N}, 75^{\circ}-110^{\circ} \mathrm{E}\right)$ shows the invasion of cold air from the stratosphere $(\sim 70 \mathrm{hPa})$ into the middle troposphere $(\sim 700 \mathrm{hPa})$ during $10-11$ June 2014 (Fig. 7a). This cold air persisted in the UT between 500-200 hPa until 21 June 2014. With the progression of time, as the temperature anomaly moves eastward in the regions of SWJ (Figs. 2a-e), the region of intrusion also shifts eastward, and accordingly the time span during which negative temperature anomalies persist over the Indian region also extends until the end of June 2014 (also seen in Fig. 6b).

We show the distribution of RH over a small region of west Asia $\left(25^{\circ}-40^{\circ} \mathrm{N}, 60^{\circ}-75^{\circ} \mathrm{E}\right)$ (Fig. $\left.7 \mathrm{~b}\right)$. This plot is shown over a smaller region, as Figs. $5 \mathrm{k}-\mathrm{O}$ show that RH anomalies are highly variable in space. Therefore, averaging it over the broader Indian region does not give meaningful representation. On 10 June 2014, the RWB was over west Asia $\left(25^{\circ}-40^{\circ} \mathrm{N}, 60^{\circ}-75^{\circ} \mathrm{E}\right)$ (Fig. 2a). This should cause an intrusion of dry stratospheric into the troposphere. Figure $7 \mathrm{~b}$ depicts this intrusion of stratospheric dry air (negative RH anomalies) during 713 June 2014 over the smaller region, as described above. This dry period persisted there until the end of June. Thus, the time-height plots of anomalies in temperature and RH shown in Figs. 7a and 7b, respectively, 

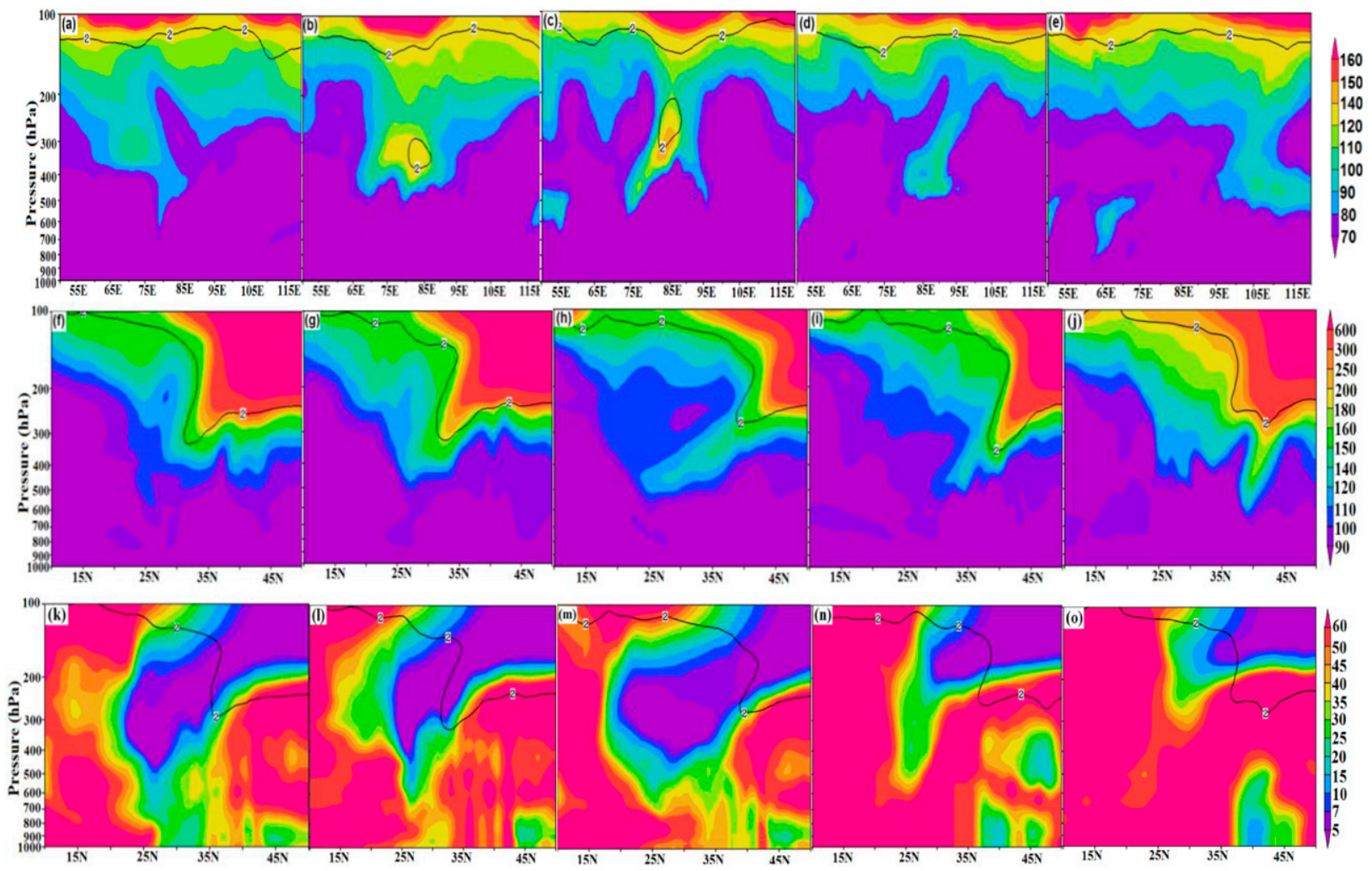

FIG. 5. Zonal cross section of ozone mixing ratios (ppb) (color shades) at $30^{\circ} \mathrm{N}$ for (a)-(e) 10, 12, 14, 16, and 18 Jun 2014 , respectively. Meridional cross section of ozone mixing ratios (ppb) for (f) $10 \mathrm{Jun}$ (averaged over $\left.60^{\circ}-75^{\circ} \mathrm{E}\right)$, (g) 12 Jun (averaged over $70^{\circ}-80^{\circ} \mathrm{E}$ ), (h) $14 \mathrm{Jun}\left(\right.$ averaged over $75^{\circ}-85^{\circ} \mathrm{E}$ ), (i) $16 \mathrm{Jun}$ (averaged over $80^{\circ}-90^{\circ} \mathrm{E}$ ), and (j) $18 \mathrm{Jun}$ (averaged over $\left.85^{\circ}-95^{\circ} \mathrm{E}\right) 2014$. (k) - (o) As in (f)-(j), but for RH (\%). The dynamic tropopause (2 PVU) is indicated by a thick black line.

reveal that the intruding air masses are anomalously cold and dry.

The same time period shows an absence of rainy (convective) spells over the monsoon trough region
(Figs. 1, 8). This could be triggered or maintained by the stratospheric intrusion over this region. This dry layer may enhance static stability and may inhibit convection on a large scale (Mapes and Zuidema 1996; Allen et al. 2009).

\section{(a)}

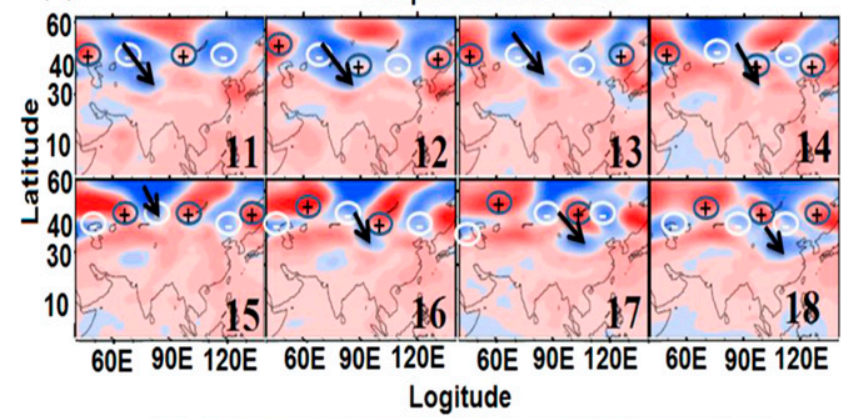
$\begin{array}{cccccccccccc}-10 & -8 & -6 & -4 & -2 & 0 & 2 & 4 & 6 & 8 & 10 & (\mathrm{~K})\end{array}$

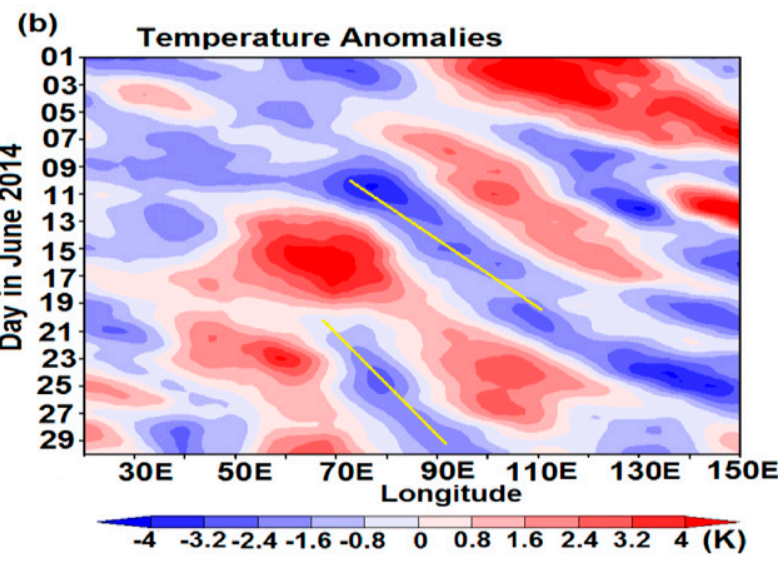

FIG. 6. (a) Daily variation of temperature (K) at $200 \mathrm{hPa}$ during 11-18 Jun 2014. Positive and negative temperature anomalies are indicated by + and - signs; (b) Hovmöller diagram of anomalies in daily temperature (K) at $400 \mathrm{hPa}$ averaged between $28^{\circ}$ and $45^{\circ} \mathrm{N}$ during June 2014 (yellow lines indicate cold temperature anomalies over the India and TP region). 

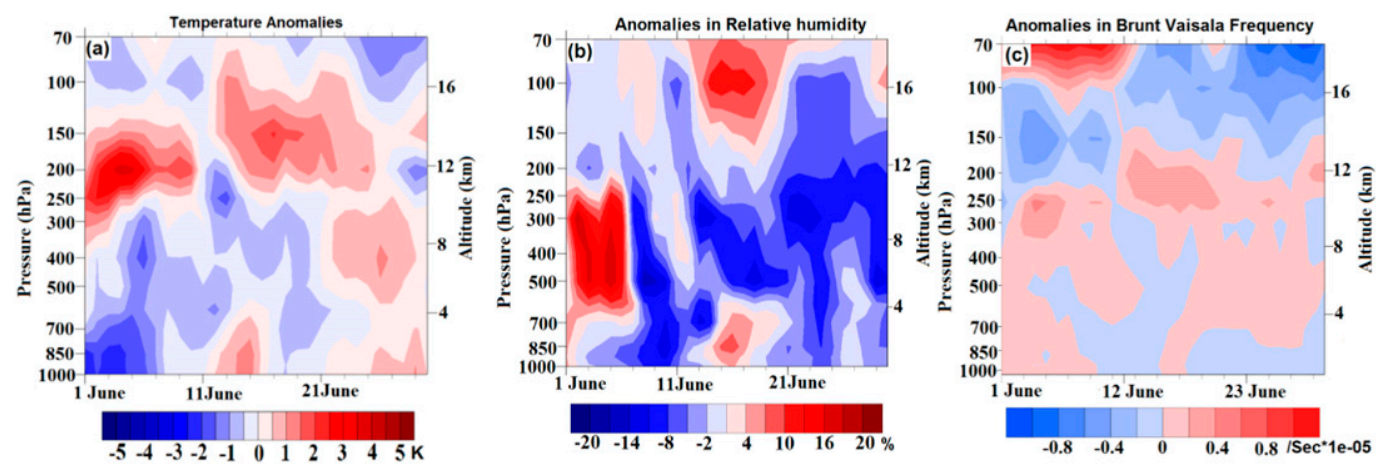

FIG. 7. Time-pressure cross section of anomalies in (a) temperature (K) averaged over $30^{\circ}-50^{\circ} \mathrm{N}, 75^{\circ}-110^{\circ} \mathrm{E}$, (b) RH (\%) averaged over $25^{\circ}-40^{\circ} \mathrm{N}, 60^{\circ}-75^{\circ} \mathrm{E}$, (c) square of Brunt Väisälä frequency $\left(\mathrm{s}^{-1}, \times 10^{-5}\right)$ averaged over $30^{\circ}-50^{\circ} \mathrm{N}, 75^{\circ}-110^{\circ} \mathrm{E}$.

Figure $7 \mathrm{c}$ shows anomalies in the Brunt Väisälä frequency averaged over the NI and TP region $\left(30^{\circ}-50^{\circ} \mathrm{N}\right.$, $75^{\circ}-110^{\circ} \mathrm{E}$ ). It shows positive anomalies (departure from climatology) after the stratospheric intrusion (1011 June). It indicates that the cold and dry layer that persisted in the upper troposphere over the Indian region had enhanced static stability for the rest of the month and might have suppressed the ISMR.

To show an influence of stratospheric intrusion on the ISMR, we plot normalized anomalies of precipitation, OLR, and upper-tropospheric temperature in Fig. 8. It depicts a surge in anomalies of PV at $200 \mathrm{hPa}$ (averaged over NI) during stratospheric intrusion days (10-18 June 2014) and after the intrusion (18 June) there is a decrease in precipitation over central India and an increase in OLR over NI and central India for the rest of the month. During intrusion days upper-tropospheric temperature anomalies $(250 \mathrm{hPa})$ over central India and the Tibetan Plateau drop, and these negative temperature anomalies persist for the rest of June 2014. Upper-tropospheric warming-cooling over the Tibetan Plateau is one of the key factors responsible for the increase-decrease in Indian precipitation by amplification-weakening of monsoon Hadley circulation (Flohn 1957; Yanai et al. 1992; Li and Yanai 1996; Wu and Zhang 1998). This indicates that cold and dry intrusion in the upper troposphere might have caused subdued convection and precipitation, resulting in a monsoon break.

\section{Discussion}

The above analysis shows that the RWB (in SWJ) that traverse NI during 10-18 June 2014 acted as an agent for transport of extratropical stratospheric cold, dry, and ozone-rich air in the UT of the Indian region. This prolonged stratosphere-troposphere exchange process could lead to ISMR reduction for a longer period and thus could additionally contribute to deficient rainfall in June 2014. It indicates that subtropical stratospheric intrusions near the Indian region or over the Indian region may be one of the major factors influencing the ISMR deficit. The direct intrusion of subtropical stratospheric cold air can have a significant effect on intraseasonal variability, as discussed in the block diagram shown in Fig. 9a. The first effect is the stabilization of atmosphere through the injection of cold and dry air in the upper troposphere. The monsoon is known to have deep convective clouds associated with synopticscale disturbances. Such deep cloud formation would indeed be hampered by the cold and dry air intrusion in the monsoon trough region (continental convergence zone) and is known for synoptic-scale events (monsoon

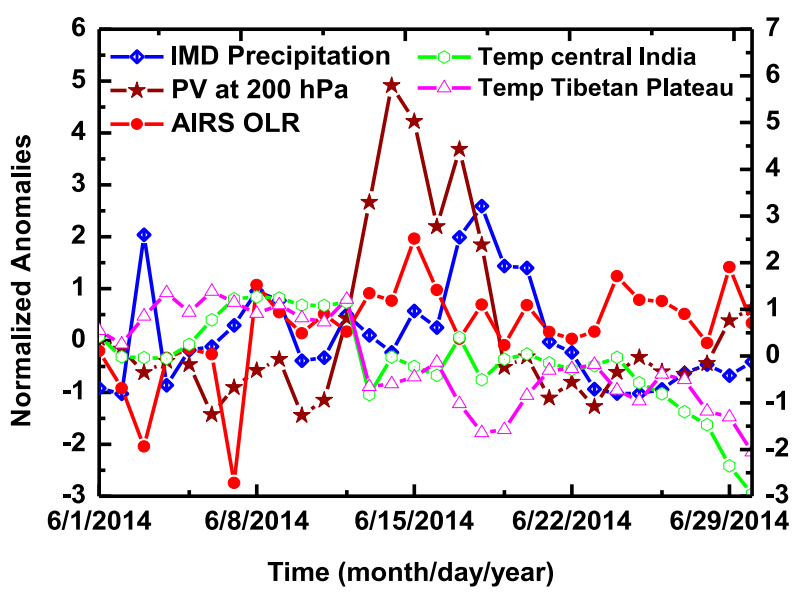

FIG. 8. Time series of normalized anomalies in ERA-Interim PV at $200 \mathrm{hPa}$ averaged over NI (brown), AIRS OLR averaged over $\mathrm{NI}$ and central India (red) $\left(12^{\circ}-40^{\circ} \mathrm{N}, 68^{\circ}-80^{\circ} \mathrm{E}\right)$, precipitation over central India (blue), and temperature $(250 \mathrm{hPa})$ over central India (green) and Tibetan Plateau (pink). 
(a)

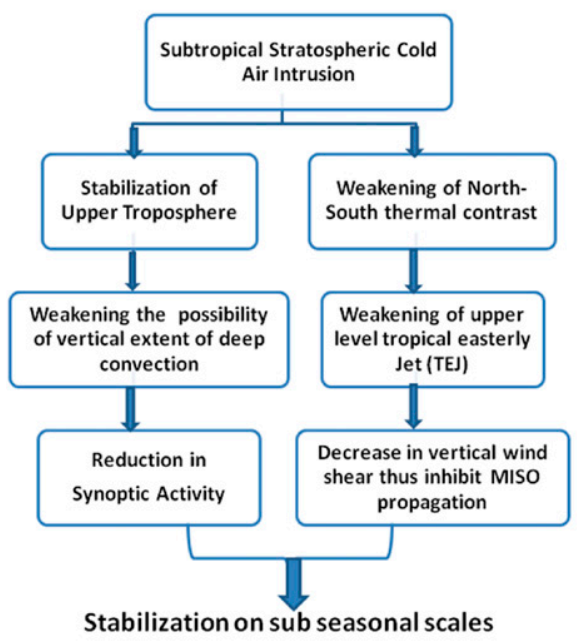

(b)

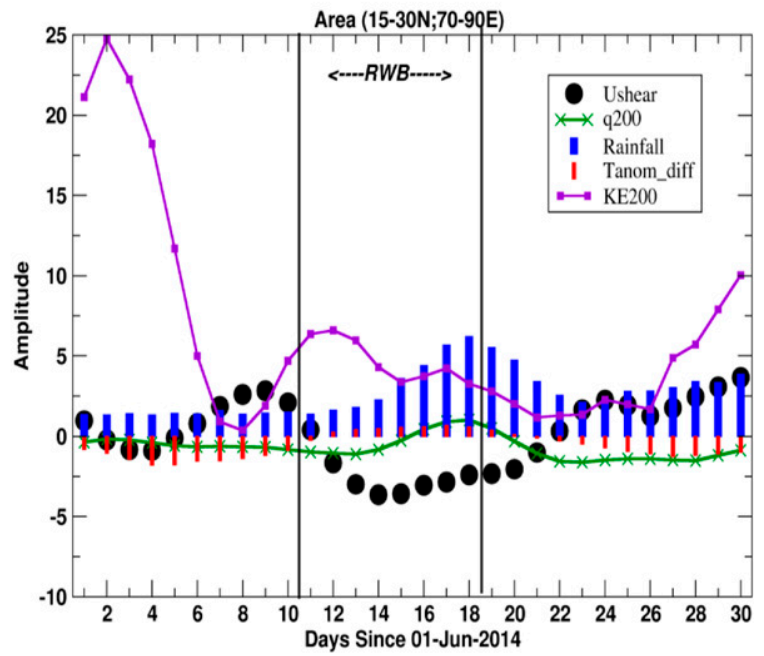

FIG. 9. (a) A schematic diagram showing the stabilization effect of stratospheric intrusion, (b) time series of rainfall (blue), vertical wind shear (black circles) (i.e., difference in zonal winds $U$ at $200-850 \mathrm{hPa}$ ), specific humidity $\left(q, \times 10^{-5}\right)$ (vertically averaged between $400-200 \mathrm{hPa}$ ), and a temperature anomaly index (red) (Tanom_diff_index) (i.e., temperature anomaly at $200-850 \mathrm{hPa}$ ) averaged over central India and zonal wind $U$ kinetic energy at $200 \mathrm{hPa}$ (purple) (ke200; i.e., $U \times U)$ averaged over $\left(15^{\circ}-30^{\circ} \mathrm{N} ; 80^{\circ}-100^{\circ} \mathrm{E}\right)$ during June 2014.

lows and depressions) giving a significant amount of rainfall over this region. The other effect is the anomalous cooling over the Tibetan Plateau and northern regions over the Himalayas, which would reduce the north-south thermal contrast, thereby weakening the tropical easterly jet (which is the resultant of the thermal wind balance). Weakening of upper-tropospheric easterlies would reduce the trademark vertical wind shear of the monsoon, thereby affecting the amplitude and northward propagation of the low-frequency (3060 day) monsoon intraseasonal oscillations. The role of zonal wind shear and moisture availability for the monsoon intraseasonal oscillations is well documented (Jiang et al. 2004; Abhik et al. 2013). Thus, the subtropical stratospheric intrusion of cold air would be affecting (reducing the amplitude) the intraseasonal variability through a negative feedback mechanism and thereby modulating the rainfall variability over the summer monsoon zone.

The above hypothesis is tested for the Rossby wave intrusion case during 10-18 June 2014, and the results are shown in Fig. 9b. It shows rainfall, vertical wind shear [i.e., difference in zonal winds $U$ at $(200-850) \mathrm{hPa}$, specific humidity $q$ (vertically averaged between 400-200 hPa), and a temperature anomaly (departure from climatology) index (Tanom_diff_index) (i.e., temperature anomaly at $200-850 \mathrm{hPa}$ ) averaged over the central India. We have also plotted zonal wind $U$ kinetic energy at $200 \mathrm{hPa}$ (ke200; i.e., $U \times U)$ over the
Bay of Bengal and adjoining central India at a slightly shifted location $\left(15^{\circ}-30^{\circ} \mathrm{N}, 80^{\circ}-100^{\circ} \mathrm{E}\right)$. Over this region, the return flow from the Tibetan anticyclone remains strong during the good monsoon period [its strength is related to the response of the north-south temperature gradient at the upper level (Xavier et al. 2007)]. To smooth the high-frequency effects we obtained the 4-days running average of these parameters. These indices are chosen to point out effects of the upper-stratospheric intrusion (cooling and drying) on the monsoon intraseasonal oscillation (zonal wind shear and $q$ ), monsoon convection (temperature anomaly index and $q$ ), and the tropical easterly jet (easterly kinetic energy of $U$ ), as indicated in the block diagram (Fig. 9a).

It can be seen that, before 10 June 2014, the rainfall is less than $2 \mathrm{~mm} \mathrm{day}^{-1}$ as the monsoon trough has yet to reach this region. Therefore, observed precipitation is due to the premonsoon (scattered or unorganized rainfall). After 10 June, the rainfall increases in this region, as the monsoon trough has arrived in this region. Rainfall steadily increases up to $6 \mathrm{~mm} \mathrm{day}^{-1}$ on 18 June. After 18 June, rainfall has decreased along with zonal wind shear becoming westerly, which is unfavorable for the northward propagation of rainband (Jiang et al. 2004). Also, upper-level warming due to deep convective heating, moisture, and the zonal kinetic energy has decreased (negative anomaly) during 18-26 June 2014. These processes are likely to happen at the same time as they are dynamically and thermodynamically linked to 

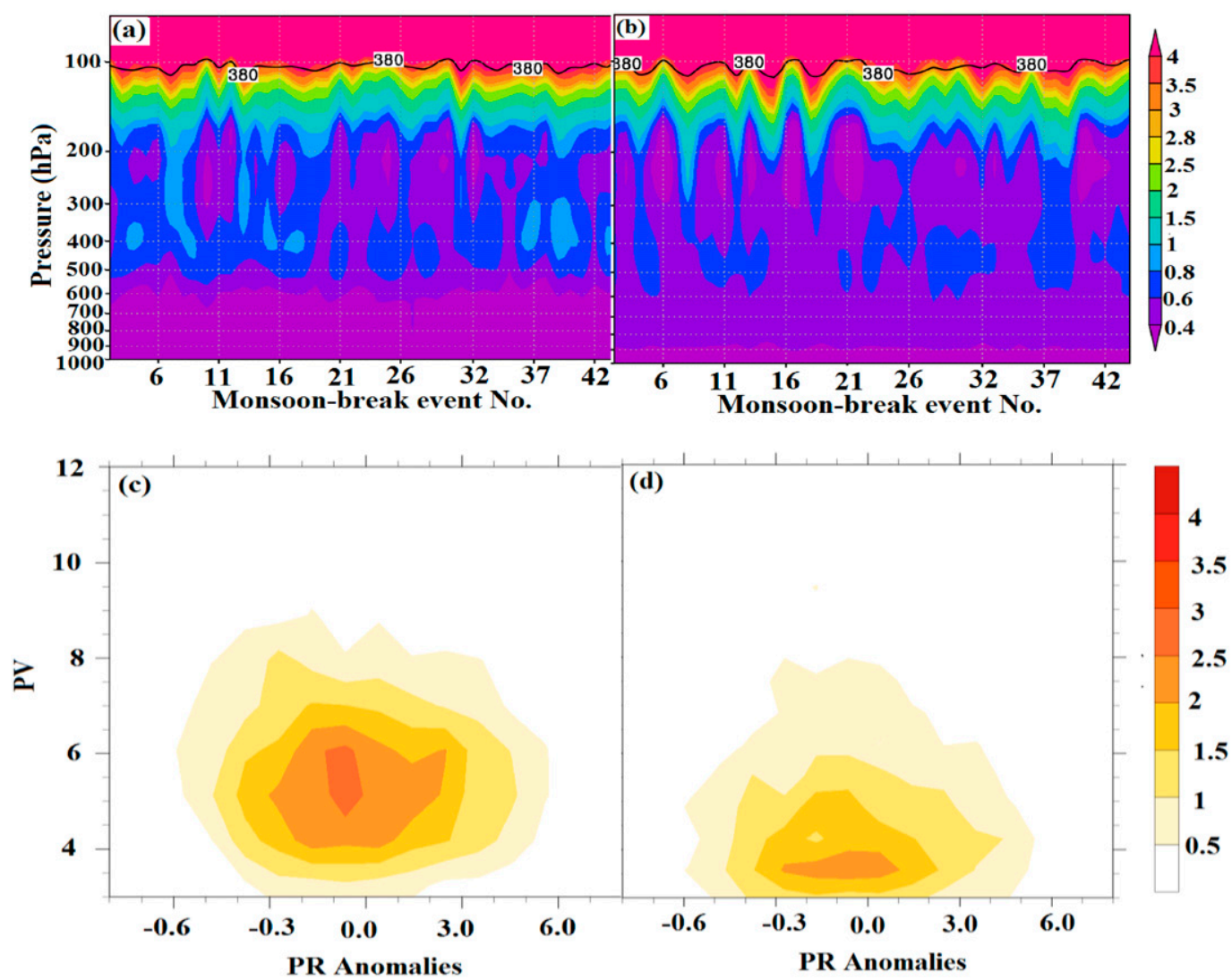

FIG. 10. Vertical distribution of PV (PVU) (color shades) for all break days listed in Table 1, averaged over (a) Region-1 and (b) Region-2. The black line corresponding to the 380-K isentropic surface represents the tropopause. Distribution frequency (\%) obtained from the bivariate probability density function is applied on anomalies in ISMR and PV for all the summer monsoon days during June-August of 1979-2007 over (c) Region-1 and (d) Region-2.

the stratospheric intrusion, which thus weakens the monsoon rain (below $2 \mathrm{~mm} \mathrm{day}^{-1}$ ) for the rest of June 2014. This indicates that the upper-stratospheric intrusion that caused cooling and drying of the UT might have weakened the intraseasonal variability, as indicated in the block diagram (Fig. 9a). Thus, the days after intrusion are marked with reduced rainfall, as hypothesized earlier.

We extend our investigation for the period 1979-2007 to understand the impact of subtropical stratospheric intrusions on the ISMR deficit. We analyze the vertical distribution of PV on break days listed in Table 1 during the period 1979-2007. Figure 10 shows the vertical distribution of PV during monsoon break days over Region-1 (Fig. 10a) and Region-2 (Fig. 10b). During most of the monsoon break days, stratospheric PV ( $>2$ PVU) pierces the tropopause and penetrates into the upper troposphere for both the regions. Streamers of $\mathrm{PV}>1$ or $\mathrm{PV}=0.8$ penetrate down to $500 \mathrm{hPa}$. During tropopause fold events, stratospheric PV $>0.8$ traveling in the upper troposphere is reported by a number of researchers (Kentarchos et al. 1998; Tyrlis et al. 2014). Table 2 gives a number of break days during 1979-2007, when the stratospheric air is identified in the UT at levels $150,250,350$, and $450 \mathrm{hPa}$ over Region- 1 and Region-2. This shows that, out of 248 break days, during 34 days, stratospheric air with PV $>0.8$ is identified at $250 \mathrm{hPa}, 49$ days at $350 \mathrm{hPa}$, and 71 days at $450 \mathrm{hPa}$ over Region-1. It should be noted that, during a larger number of break days, stratospheric air is identified at $450 \mathrm{hPa}$ rather than at 350 or $250 \mathrm{hPa}$. This may be as a result of eddy shedding. Over Region-2, air mass with $\mathrm{PV}>0.8$ is identified during 13 days at $250 \mathrm{hPa}, 2$ days at $350 \mathrm{hPa}$, and 1 day at $450 \mathrm{hPa}$.

To show the relation of stratospheric intrusions with ISMR, we exhibit BPDF between daily ISMR anomalies over central India and PV at $250 \mathrm{hPa}$ during 1979-2007 over Region-1 and Region-2, respectively (refer to Figs. 10c,d). The frequency distribution is negatively skewed over Region-1 and Region-2. This indicates the 
TABLE 2. Number of monsoon break days when stratospheric PV intrusions are identified at the pressure levels in the UT over Region-1 and Region-2.

\begin{tabular}{ccccc}
\hline \hline PV during break days & Level $150 \mathrm{hPa}$ & Level $250 \mathrm{hPa}$ & Level $350 \mathrm{hPa}$ & Level $450 \mathrm{hPa}$ \\
\hline & & Region- 1 & \\
$\mathrm{PV}>2$ & 7 & 1 day & 1 day & 1 day \\
$\mathrm{PV}>1.5$ & 52 & 1 day & 1 day & 1 day \\
$\mathrm{PV}>1$ & 179 & 9 & 9 & 1 day \\
$\mathrm{PV}>0.8$ & 211 & Region-2 & 49 & 71 \\
$\mathrm{PV}>2$ & 2 & 1 day & 1 day & 1 day \\
$\mathrm{PV}>1.5$ & 69 & 1 day & 1 day & 1 day \\
$\mathrm{PV}>1$ & 154 & 13 & 2 day & 1 day \\
$\mathrm{PV}>0.8$ & 189 & & 2 & 1 day \\
\hline
\end{tabular}

likelihood of deficit monsoon activity (negative rainfall anomalies) during stratospheric intrusion $(\mathrm{PV}>2)$.

\section{Conclusions}

This paper reports that the subtropical stratospheric intrusion is likely to aid the development of longer spells of subdued rainfall during the Indian summer monsoon season. The prolonged hiatus in monsoon propagation during the onset phase of the monsoon, during June 2014 , is studied in the context of subtropical stratospheric intrusion. A life cycle of subtropical stratospheric intrusion is presented that could be responsible for the weak monsoon activity after the onset phase.

ERA-Interim shows that deep stratospheric intrusion due to RWB occurred over NI and adjacent regions during 10-18 June 2014. These intrusions traversed toward the NI along the subtropical westerly jet and shed eddies. Eddy shedding occurred westward and to the south of the subtropical westerly jet stream. These eddies propagated downward into the midtroposphere. During this event, RWB was intense, and it split the Asian summer monsoon anticyclone into Iranian and Tibetan anticyclones. The tropopause fold associated with RWB penetrated between these anticyclones into the upper troposphere $(\sim 300 \mathrm{hPa})$. It transports extratropical stratospheric air $(\mathrm{PV}>2)$ into the UT over NI. An extremely intense RWB event was located over the Tibetan Plateau on 14 June 2014. On this day, tropopause fold penetrated deeper in the troposphere and shed eddies down to $300 \mathrm{hPa}$. Intrusions are associated with transport of extremely dry $(\mathrm{RH}<5 \%)$, anomalous cold (temperature $<5 \mathrm{~K}$ ), and ozone-rich $[\sim(140-160) \mathrm{ppb}]$ air into the troposphere $(\sim 500 \mathrm{hPa})$ over India. These layers persisted until the end of June, resulting in subdued convection. Another important conclusion is that the stratospheric intrusion period was marked with an abrupt increase in static stability of the troposphere.
The anomalously dry and cold upper troposphere weakened the upper-tropospheric north-south temperature gradient, which might also have inhibited northward propagation of large-scale convection and was responsible for the India monsoon deficit during June 2014. Our analysis also shows that, after the RWB event (18 June 2014) zonal wind shear became westerly, which is unfavorable for the northward propagation of the rainband (Jiang et al. 2004). Upper-level warming due to deep convective heating, moisture, and the zonal kinetic energy decreased during 18-26 June 2014. This indicates that the upper-stratospheric intrusion that caused cooling and drying in the upper troposphere might have weakened the monsoon intraseasonal variability.

We extend our investigation for the period 1979-2007 to understand the impact of subtropical stratospheric intrusions on the ISMR. Distributions of PV during break events show that during most of the monsoon break cases streamers of stratospheric $\mathrm{PV}$ protrude to $\sim 150 \mathrm{hPa}$, and a few extend down to $500 \mathrm{hPa}$. The bivariate probability distribution function (BPDF) applied on daily ISMR anomalies over central India and $\mathrm{PV}$ at $250 \mathrm{hPa}$ is negatively skewed, indicating a likelihood of a deficit monsoon during stratospheric intrusion $(\mathrm{PV}>2)$. It indicates that subtropical stratospheric intrusion near the Indian region may be one of the factors influencing the ISMR deficit.

Acknowledgments. The authors acknowledges with gratitude Dr. Krishnan, Executive Director of CCCR, IITM, for his encouragement during the course of this study. The authors are thankful to team members of ERA-Interim (http://apps.ecmwf.int/datasets/data/ interim-full-daily/levtype $=\mathrm{pl} /$ ) and AIRS (http://airs. jpl.nasa.gov/data/get_data) for providing data. We also thank the anonymous reviewers and Dr. Darryn Waugh, Editor, Journal of Climate, for their valuable suggestions for improvement of this manuscript. Authors 
acknowledge language editing help from Prof. Gordon Shepherd, York University, Toronto, Canada and Dr. A. M. Selvam, ex-deputy director, Indian Institute of Tropical Meteorology, Pune, India.

\section{REFERENCES}

Abhik, S., M. Halder, P. Mukhopadhyay, X. Jiang, and B. N. Goswami, 2013: A possible new mechanism for northward propagation of boreal summer intraseasonal oscillations based on TRMM and MERRA reanalysis. Climate Dyn., 40, 16111624, doi:10.1007/s00382-012-1425-x.

Allen, G., G. Vaughn, D. Brunner, P. T. May, W. Heyes, P. Minnis, and J. K. Ayers, 2009: Modulation of tropical convection by breaking Rossby waves. Quart. J. Roy. Meteor. Soc., 135, 125137, doi:10.1002/qj.349.

Appenzeller, A., and H. C. Davies, 1992: Structure of stratospheric intrusions into the troposphere. Nature, 358, 570-572, doi:10.1038/358570a0.

Ashok, K., Z. Guan, H. N. Saji, and T. Yamagata, 2004: Individual and combined influences of ENSO and the Indian ocean dipole on the Indian summer monsoon. J. Climate, 17, 3141-3155, doi:10.1175/1520-0442(2004)017<3141:IACIOE > 2.0.CO;2.

Barnes, E. A., and D. L. Hartmann, 2012: Detection of Rossby wave breaking and its response to shifts of the midlatitude jet with climate change. J. Geophys. Res., 117, D09117, doi:10.1029/2011JG001749.

Biswas, N. C., U. S. De, and D. R. Sikka, 1998: The role of Himalayan massif Tibetan plateau and mid-tropospheric subtropical ridge over north India during the advance phase of the south west monsoon. Mausam, 49, 285-300.

Dee, D. P., and Coauthors, 2011: The ERA-Interim reanalysis: Configuration and performance of the data assimilation system. Quart. J. Roy. Meteor. Soc., 137, 553-597, doi:10.1002/ qj.828.

Dunkerton, T. J., 1995: Evidence of meridional motion in the summer lower stratosphere adjacent to monsoon regions. J. Geophys. Res., 100, 16 675-16 688, doi:10.1029/95JD01263.

Fadnavis, S., T. Chakraborty, and G. Beig, 2010: Seasonal stratospheric intrusion of ozone in the upper troposphere over India. Ann. Geophys., 28, 2149-2159, doi:10.5194/ angeo-28-2149-2010.

Fischer, H., and Coauthors, 2000: Tracer correlations in the northern high latitude lowermost stratosphere: Influence of cross-tropopause mass exchange. Geophys. Res. Lett., 27, 97 100, doi:10.1029/1999GL010879.

Flohn, H., 1957: Large-scale aspects of the "summer monsoon" in South and East Asia. J. Meteor. Soc. Japan, 75, 180-186, doi:551.553.21:551.589.5.

Gadgil, S., and S. Gadgil, 2006: The Indian Monsoon, GDP and agriculture. Econ. Political Wkly., 41, 4887-4895.

Garny, H., and W. J. Randel, 2013: Dynamic variability of the Asian monsoon anticyclone observed in potential vorticity and correlations with tracer distributions. J. Geophys. Res. Atmos., 118, 13 421-13 433, doi:10.1002/2013JD020908.

Goswami, B. N., 2012: South Asian monsoon. Intraseasonal Variability in the Atmosphere-Ocean Climate System, 2nd ed. W. K.-M. Lau and D. E. Waliser, Eds., Springer-Verlag, 21-72.

He, H., J. W. McGinnis, Z. Song, and M. Yanai, 1987: Onset of the Asian summer monsoon in 1979 and the effect of the Tibetan Plateau. Mon. Wea. Rev., 115, 1966-1995, doi:10.1175/ 1520-0493(1987)115<1966:OOTASM>2.0.CO;2.
Holbrook N. J., and Coauthors, 2014: Decadal climate variability and cross-scale interactions: ICCL 2013 expert assessment workshop. Bull. Amer. Meteor. Soc., 95, ES155-ES158, doi:10.1175/BAMS-D-13-00201.1.

Holton, J. R., P. H. Haynes, M. E. Mcintyre, A. R. Douglass, R. B Rood, and L. Pfister, 1995: Stratosphere-troposphere exchange. Rev. Geophys., 33, 403-439, doi:10.1029/95RG02097.

Homeyer, C. R., and K. P. Bowman, 2013: Rossby wave breaking and transport between the tropics and extratropics above the subtropical jet. J. Atmos. Sci., 70, 607-626, doi:10.1175/ JAS-D-12-0198.1.

Hoskins, B. J., M. E. McIntyre, and A. W. Robertson, 1985: On the use and significance of isentropic potential vorticity maps. Quart. J. Roy. Meteor. Soc., 111, 877-946, doi:10.1002/ qj. 49711147002 .

Hsu, C. J., and R. A. Plumb, 2000: Nonaxisymmetric thermally driven circulations and upper-tropospheric monsoon dynamics. J. Atmos. Sci., 57, 1255-1276, doi:10.1175/ 1520-0469(2000)057<1255:NTDCAU>2.0.CO;2.

Jiang, X., T. Li, and B. Wang, 2004: Structures and mechanisms of the northward propagating boreal summer intraseasonal oscillation. J. Climate, 17, 1022-1039, doi:10.1175/1520-0442(2004)017<1022: SAMOTN $>2.0 . \mathrm{CO} ; 2$.

Kentarchos, A. S., T. D. Davies, and C. S. Zerefos, 1998: A low latitude stratospheric intrusion associated with a cut-off low Geophys. Res. Lett., 25, 67-70, doi:10.1029/97GL03351.

Konopka, P., J.-U. Grooß, G. Günther, F. Ploeger, R. Pommrich, R. Müller, and N. Livesey, 2010: Annual cycle of ozone at and above the tropical tropopause: Observations versus simulations with the Chemical Lagrangian Model of the Stratosphere (CLaMS). Atmos. Chem. Phys., 10, 121-132, doi:10.5194/ acp-10-121-2010.

Krishnamurti, T. N., 1985: Summer monsoon experiment-A review. Mon. Wea. Rev., 113, 1590-1626, doi:10.1175/ 1520-0493(1985)113<1590:SMER > 2.0.CO;2.

Krishnan, R., C. Zhang, and M. Sugi, 2000: Dynamics of breaks in the Indian summer monsoon. J. Atmos. Sci., 57, 1354-1372, doi:10.1175/1520-0469(2000)057<1354:DOBITI > 2.0.CO;2.

_- , V. Kumar, M. Sugi, and J. Yoshimura, 2009: Internal feedbacks from monsoon-midlatitude interactions during droughts in the Indian summer monsoon. J. Atmos. Sci., 66, 553-578, doi:10.1175/2008JAS2723.1.

Li, C., and M. Yanai, 1996: The onset and interannual variability of the Asian summer monsoon in relation to land-sea thermal contrast J. Climate, 9, 358-375, doi:10.1175/1520-0442(1996)009<0358: TOAIVO $>2.0 . \mathrm{CO} ; 2$.

Mapes, B. E., and P. Zuidema, 1996: Radiative-dynamical consequences of dry tongues in the tropical troposphere. J. Atmos. Sci., 53, 620-638, doi:10.1175/1520-0469(1996)053<0620: $\mathrm{RDCODT}>2.0 . \mathrm{CO} ; 2$.

McIntyre, M. E., and T. N. Palmer, 1985: A note on the general concept of wave breaking for Rossby and gravity waves. Pure Appl. Geophys., 123, 964-975, doi:10.1007/BF00876984.

Nützel, M., M. Dameris, and H. Garny, 2016: Movement, drivers and bimodality of the South Asian high? Atmos. Chem. Phys., 16, 14 755-14 774, doi:10.5194/acp-16-14755-2016.

Pan, L. L., W. J. Randel, B. L. Gary, M. J. Mahoney, and E. J. Hintsa, 2004: Definitions and sharpness of the extratropica tropopause: A trace gas perspective. J. Geophys. Res., 109, D23103, doi:10.1029/2004JD004982.

Ploeger, F., and Coauthors, 2012: Horizontal transport affecting trace gas seasonality in the tropical tropopause layer (TTL) J. Geophys. Res., 117, D09303, doi:10.1029/2011JD017267. 
Popovic, J. M., and R. A. Plumb, 2001: Eddy shedding from the upper-tropospheric Asian monsoon anticyclone. J. Atmos. Sci., 58, 93-104, doi:10.1175/1520-0469(2001)058<0093: ESFTUT $>2.0 . \mathrm{CO} ; 2$.

Rajeevan, M., S. Gadgil, and J. Bhate, 2010: Active and break spells of the Indian summer monsoon. J. Earth Syst. Sci., 119, 229247, doi:10.1007/s12040-010-0019-4.

Raju, P. V. S., U. C. Mohanty, and R. Bhatla, 2005: Onset characteristics of the southwest monsoon over India. Int J. Climatol., 25, 167-182, doi:10.1002/joc.1121.

Ramaswamy, C., 1962: Breaks in the Indian summer monsoon as a phenomenon of interaction between the easterly and the subtropical westerly jet streams. Tellus, 14, 337-349, doi:10.3402/ tellusa.v14i3.9560.

Reid, H. J., and G. Vaughan, 2004: Convective mixing in a tropopause fold. Quart. J. Roy. Meteor. Soc., 130, 1195-1212, doi:10.1256/qj.03.21.

Ren-Chang, Y., B. Jian-Chun, and F. Q. Jun, 2011: The impact of the South Asia high bimodality on the chemical composition of the upper troposphere and lower stratosphere. Atmos. Oceanic Sci. Lett., 4, 229-234, doi:10.1080/ 16742834.2011.11446934.

Samanta, D., M. K. Dash, B. N. Goswami, and P. C. Pandey, 2016: Extratropical anticyclonic Rossby wave breaking and Indian summer monsoon failure. Climate Dyn., 46, 1547-1562, doi:10.1007/s00382-015-2661-7.

Scott, R. K., and J.-P. Cammas, 2002: Wave breaking and mixing at the subtropical tropopause. J. Atmos. Sci., 59, 2347-2361, doi:10.1175/1520-0469(2002)059<2347:WBAMAT>2.0.CO;2.

Strong, C., and G. Magnusdottir, 2008: Tropospheric Rossby wave breaking and the NAO/NAM. J. Atmos. Sci., 65, 2861-2876, doi:10.1175/2008JAS2632.1.

Subramanya, K., 1984: Engineering Hydrology. McGraw Hill, $392 \mathrm{pp}$.

Tyrlis, E., B. Škerlak, M. Sprenger, H. Wernli, G. Zittis, and J. Lelieveld, 2014: On the linkage between the Asian summer monsoon and tropopause fold activity over the eastern
Mediterranean and the Middle East. J. Geophys. Res., 119, 3202-3221, doi:10.1002/2013JD021113.

Vogel, B., and Coauthors, 2014: Fast transport from Southeast Asia boundary layer sources to northern Europe: Rapid uplift in typhoons and eastward eddy shedding of the Asian monsoon anticyclone. Atmos. Chem. Phys., 14, 12745-12762, doi:10.5194/acp-14-12745-2014.

Waugh, D. W., 2005: Impact of potential vorticity intrusions on subtropical upper tropospheric humidity. J. Geophys. Res., 110, D11305, doi:10.1029/2004JD005664.

, and L. M. Polvani, 2000: Intrusions into the tropical upper troposphere. Geophys. Res. Lett., 27, 3857-3860, doi:10.1029/ 2000GL012250.

- and B. M. Funatsu, 2003: Intrusions into the tropical upper troposphere: Three-dimensional structure and accompanying ozone and OLR distributions. J. Atmos. Sci., 60, 637-653, doi:10.1175/1520-0469(2003)060<0637:IITTUT>2.0.CO;2.

Weigel, K., and Coauthors, 2012: A stratospheric intrusion at the subtropical jet over the Mediterranean Sea: Air-borne remote sensing observations and model results. Atmos. Chem. Phys., 12, 8423-8438, doi:10.5194/acp-12-8423-2012.

Wu, G. X., and Y. S. Zhang, 1998: Tibetan Plateau forcing and the timing of the monsoon onset over South Asia and the South China Sea. Mon. Wea. Rev., 126, 913-927, doi:10.1175/ 1520-0493(1998)126<0913:TPFATT >2.0.CO;2.

Xavier, P. K., C. Marzin, and B. N. Goswami, 2007: An objective definition of the Indian summer monsoon season and a new perspective on the ENSO-monsoon relationship. Quart. J. Roy. Meteor. Soc., 133, 749-764, doi:10.1002/qj.45.

Yanai, M., C. Li, and Z. Song, 1992: Seasonal heating of the Tibetan Plateau and its effects on the evolution of the Asian summer monsoon. J. Meteor. Soc. Japan, 70, 189-221, doi:10.2151/ jmsj1965.70.1B_319.

Zhang, Q., G. X. Wu, and Y. Qian, 2002: The bimodality of $100 \mathrm{hPa}$ South Asia high and its relationship to the climate anomaly over East Asia in summer. J. Meteor. Soc. Japan, 80, 733-744, doi:10.2151/jmsj.80.733. 